\title{
Russia - Measures Affecting the Importation of Railway Equipment and Parts Thereof, DS499 - ERRATUM
}

\author{
Marcus Sohlberg
}

https://doi.org/10.1017/S1474745620000233, Published by Cambridge University Press, 8 June 2020 .

In this case summary a number of text corrections were not made in the final published version. These text corrections are detailed below.

Page 477 Line 4 ' $\ldots$ as suppliers from the other countries ...' should read '.. as suppliers from other countries...'

Page 477 Line 33 '... confidence that products conform ...' should read '... confidence that the products conform ...'

Page 477 Footnote 4 ' '.. Panel Report, Russia-Railway Equipment, para. 7.544. ...' should read '... Ibid. para. 7.544. ...'

Page 478 Footnote 7 '... Ibid. paras. 5.200-5.201. ...' should read '... Panel Report, Russia-Railway Equipment. ...'

Page 478 Line 21 '... Marcus Sohlberg Counsel, White \& Case LLP, Geneva, Switzerland, but written in their personal capacity. ...' should read '... Marcus Sohlberg. Counsel, White \& Case LLP, Geneva, Switzerland, but written in personal capacity. ...'

The publisher apologises for these errors.

\section{Reference}

M. Sohlberg, 'Russia - Measures Affecting the Importation of Railway Equipment and Parts Thereof, DS499', 19(3) World Trade Review (2020), 476-478. https://doi.org/10.1017/S1474745620000233

Cite this article: Sohlberg M (2020). Russia-Measures Affecting the Importation of Railway Equipment and Parts Thereof, DS499 - ERRATUM. World Trade Review 19, 621-621. https://doi.org/10.1017/S1474745620000464

(c) The Author(s), 2020. Published by Cambridge University Press 